\title{
A Dataset of Lost Opportunities The Case of 63 Developed And Emerging Countries Amid The COVID-19 Pandemic
}

Elena G. Popkova ( $\square$ elenapopkova@yahoo.com )

Moscow State Institute of International Relations (MGIMO)

\section{Aleksei V. Bogoviz}

Independent researcher, Moscow, Russia

Svetlana V. Lobova

Altai State University, Barnaul, Russia

Elena N. Makarenko

Rostov State University of Economics

Bruno S. Sergi

Harvard University

\section{Research Article}

Keywords: COVID-19 crisis, cross-country overview, development of the world economy, sustainability, stability, rapid digital growth, dataset, Big data ethics.

Posted Date: December 22nd, 2021

DOI: https://doi.org/10.21203/rs.3.rs-1181988/v1

License: (c) (1) This work is licensed under a Creative Commons Attribution 4.0 International License. Read Full License 


\section{Abstract}

The dataset provides the statistics on digital competitiveness, sustainable development, and the COVID19 cases for 63 developed and developing countries. The dataset calculates digital competitiveness and sustainable development under the adverse impact of the pandemic in 2020. Unlike the stark change compared with 2019, it clears the estimated growth of the other factors' influence and characterizes the effect of the pandemic and the COVID-19 crisis. Practical significance also comprises evaluating wasted opportunities in 2020 and increasing digital competitiveness and sustainable development, which reflect the difference between simple growth indicators in 2020 and 2019 and growth under the pandemic's influence. Another advantage of this paper is the forecasting advantage and the alternativeness of the considered scenarios, which allows implementing the estimates in a broad range of scientific studies. The case of Australia and the world economy's forecast for 2021 are elaborated on in the paper.

\section{Introduction}

Disinformation occupies an important place among the ethical problems of creating, organizing, disseminating, and using the information in the age of Big data. It means not only the provision of knowingly false data but also - which is much more common - the provision of incomplete data or insufficiently explained data, leading to their distorted interpretations.

This ethical issue has become particularly acute in the face of the COVID-19 pandemic and crisis. So, for example, the number of cases is indicated in the official news and on the official websites of organizations that maintain statistics on COVID-19. During periods of increasing incidence, data are published in absolute terms on the number of new cases of coronavirus infection. However, upon in-depth examination, it can be seen that the incidence of COVID-19 in most countries does not exceed $1 \%$ of the population and on an accrual basis (for the entire period of the pandemic).

In absolute terms, 10,000 new cases of morbidity sound threatening, and in relative terms, this figure does not even reach half a per cent of the population. Providing incomplete information that does not allow one to form a systematic understanding of data is an urgent problem of Big data ethics.

Most of the Big data provided by official statistics are annually updated statistical databases or reports containing the current estimated values of indicators and the dynamics of their change in comparison with the past. Except for rare cases (for example, WHO Coronavirus Dashboard), Big data reflects the state of affairs in 2020 and not specifically targeted statistics on the COVID-19 pandemic and crisis.

However, in these reports, the dynamics of changes in statistical indicators in 2020 (compared to 2019) are perceived as a direct result of the COVID-19 pandemic and crisis. This is especially the case for the IMD digital economy statistics and the UNDP sustainable development statistics. Because of this ethical issue, the 2020 IMD and UNDP Big data are perceived as sources of information on the impact of the COVID-19 pandemic and crisis on the digital economy and sustainable development, respectively. In 
reality, this Big data reflects the simple dynamics of statistical indicators under many factors. It is unknown whether the impact of the COVID-19 pandemic and crisis was determined.

To solve the posed ethical problem, this article developed a dataset in which Big data on digital competitiveness and sustainable development in 2020 are cleared of the influence of other factors, due to which the dataset characterizes the direct (isolated) impact of the COVID-19 pandemic and crisis, preventing data corruption.

\section{Literature Review}

The issues of economic development after the COVID-19 crisis with particular attention to sustainability are discussed in Perry [6], Le et al. [7], Asiedu et al. [8], Gitonga et al. [9], Hellewell et al. [10], Anderson et al. [11], Mandel and Veetil [12], Ivanov [13], Inoue and Todo [14], Shan et al. [15], Yekefallah et al. [16], Olonade et al. [17], Prayitno et al. [18] and Chalongvorachai and Woraratpanya [19] and formed the theoretical basis of the research.

The article is based on the theory of ethical use of information, stated in the studies of Emmanuel et al. [20], Ferretti et al. [21, 22], Grybauskas et al. [23], Jantavongso and Fusiripong [24], Ngan and Kelmenson [25], Novak and Pavlicek [26], Reps et al. [27], Robinson [28], Roche and Jamal [29], Seliya et al. [thirty].

In the existing theory, the ethics of Big data is considered from the standpoint of the reliability of statistical information, that is, from the side of the data source (statistical service, research organization, etc.). The reliability of data is the only criterion for their ethics. At the same time, the perception of information and the possibility and correctness of its interpretation by data users remains unexplored, which is a research gap filled in this article.

\section{Data Description}

The dataset is the numerical data array in a Microsoft Excel document. The official statistics data are shown against the white background, and new original data obtained in the dataset is directed against the grey backdrop. We preserve this differentiation in this paper. Since the dataset contains data on sixtythree countries, the first ten countries (in alphabetical order) are shown here. We offer the primary statistical data collected and systematized (see Table 1).

Table 1 The basic statistics on economic development in 2019-2020 and its growth, and statistics on the pandemic and the COVID-19 crisis 


\begin{tabular}{|c|c|c|c|c|c|c|c|}
\hline \multirow[t]{3}{*}{ Country } & \multicolumn{6}{|c|}{ Basic statistics on economic development } & \multirow{3}{*}{$\begin{array}{l}\text { Statistics on the pandemic } \\
\text { and the COVID-19 crisis } \\
\text { Number of cases per } 1,000 \\
\text { people }\end{array}$} \\
\hline & \multicolumn{3}{|c|}{$\begin{array}{l}\text { Digital competitiveness } \\
\text { index, points } 1-100\end{array}$} & \multicolumn{3}{|c|}{$\begin{array}{l}\text { Sustainable development } \\
\text { index, points } 1-100\end{array}$} & \\
\hline & 2019 & 2020 & $\begin{array}{l}\text { Growth, } \\
\%\end{array}$ & 2019 & 2020 & $\begin{array}{l}\text { Growth, } \\
\%\end{array}$ & \\
\hline Australia & 8.9 & 85.5 & -3.9 & 73.9 & 74.9 & 1.3 & 1.1 \\
\hline Austria & 4.5 & 83.1 & -1.6 & 81.1 & 80.7 & -0.5 & 14.1 \\
\hline Argentina & 6.0 & 48.8 & -13.0 & 72.4 & 73.2 & 1.1 & 26.7 \\
\hline Belgium & 2.5 & 77.0 & -6.7 & 78.9 & 80.0 & 1.3 & 39.5 \\
\hline Bulgaria & 3.7 & 56.3 & -11.6 & 74.5 & 74.8 & 0.4 & 9.2 \\
\hline Brazil & 57.3 & 52.1 & -9.2 & 70.6 & 72.7 & 2.9 & 26.4 \\
\hline Hungary & 5.5 & 55.9 & -14.6 & 76.9 & 77.3 & 0.6 & 9.4 \\
\hline Venezuela & 7.8 & 24.0 & -13.6 & 63.1 & 61.7 & -2.3 & 2.9 \\
\hline Germany & 6.2 & 81.1 & -6.0 & 81.1 & 80.8 & -0.4 & 7.2 \\
\hline Greece & 9.6 & 56.2 & -5.7 & 71.4 & 74.3 & 4.1 & 4.1 \\
\hline
\end{tabular}

Source: Fragment of the dataset [5]

According to the new data presented in Table 1, the growth (reduction) of Australia's digital competitiveness index in 2020 is $-3.853 \%$ compared to 2019 . The growth of the sustainable development index is $+1.313 \%$. The number of COVID-19 cases in Australia is extremely low: 1.07 per 1,000 people, i.e., $1.07 / 1000=0.00107 \%$.

\section{Experimental Design, Materials, and Methods}

Based on the basic data, the fragment of which is given in Table 1, regression curves are built into the dataset - they reflect the growth of the digital competitiveness index and the sustainable development index on the number of COVID-19 cases (Figures 1 and 2).

As shown in Figure 1, an increase in COVID-19 cases per 1,000 people reduces the digital competitiveness index by $0.0349 \%$. Therefore, the pandemic slows down digitalization. One cannot ignore the low value of the correlation coefficient $(0.48 \%)$, which shows that the pandemic, and the COVID-19 crisis are ordinary (not the primary) digital growth factors in 2020.

As shown in Figure 2, an increase in the number of COVID-19 cases per 1,000 people leads to the sustainable development index's growth by $0.0004 \%$. Therefore, the pandemic only slows down digitalization. One cannot ignore a shallow value of the correlation coefficient (it moves toward zero), 
which shows that the pandemic and the COVID-19 crisis are insignificant factors in the world economy's sustainable development in 2020.

The regression coefficients (Figures 1 and 2 ) allow the digital competitiveness index's growth and the sustainable development index directly under the crisis's isolated influence in 2020. Opportunities for each country's lost development due to the crisis in 2020 are given in Table 2.

Table 2 Growth under the crisis's influence and lost opportunities for digital and sustainable development in 2020

\begin{tabular}{|lllll|}
\hline Country & \multicolumn{2}{l}{$\begin{array}{l}\text { Growth under the influence of the crisis in } \\
\mathbf{2 0 2 0}\end{array}$} & $\begin{array}{l}\text { Opportunities for development in 2020 } \\
\text { that are lost due to the crisis }\end{array}$ \\
\cline { 2 - 3 } & $\begin{array}{l}\text { Digital } \\
\text { competitiveness } \\
\text { index, \% }\end{array}$ & $\begin{array}{l}\text { Sustainable } \\
\text { development index } \\
\text { \% }\end{array}$ & $\begin{array}{l}\text { Digital } \\
\text { competitiveness } \\
\text { index, \% }\end{array}$ & $\begin{array}{l}\text { Sustainable } \\
\text { development index, } \\
\%\end{array}$ \\
\hline Australia & -6.998 & 1.090 & 3.145 & 0.222 \\
\hline Austria & -7.451 & 1.096 & 5.860 & -1.589 \\
\hline Argentina & -7.890 & 1.101 & -5.064 & -0.037 \\
\hline Belgium & -8.339 & 1.106 & 1.654 & 0.238 \\
\hline Bulgaria & -7.282 & 1.094 & -4.291 & -0.731 \\
\hline Brazil & -7.882 & 1.100 & -1.274 & 1.832 \\
\hline Hungary & -7.287 & 1.094 & -7.312 & -0.521 \\
\hline Venezuela & -7.060 & 1.091 & -6.527 & -3.341 \\
\hline Germany & -7.211 & 1.093 & 1.233 & -1.500 \\
\hline Greece & -7.104 & 1.092 & 1.362 & 3.012 \\
\hline
\end{tabular}

Source: Fragment of the dataset [5]

\section{The case of Australia}

Let us consider the case of Australia. To calculate the digital competitiveness index's growth amid the 2020 crisis, we value the number of cases in Australia (1.07) in the equation in Figure 1. We get the following equation:

$$
-0.0349 * 1.07+6.9602=-6.998 \%
$$

To determine the growth of the digital competitiveness index under the influence of the 2020 crisis, we put the value of the number of cases in Australia (1.07) in the equation in Figure 2. The following equation is obtained: 


\section{$0.0004 * 1.07+1.0899=1.090 \%$}

Opportunities lost for the Australian economy's digital development due to the crisis in 2020 are determined as the difference between general growth from Table 1 and growth under the crisis's influence from Table 2: $-3.852-(-6.998)=3.146 \%$. This means that if there had been no pandemic and the COVID19 crisis, Australia's digital competitiveness index would have grown by $3.145 \%$ in 2020 compared to 2019, emphasizing the crisis's negative influence on the Australian economy.

The opportunities for sustainable development of the Australian economy amid 2020 are determined as the difference between general growth from Table 1 and growth under the influence of the crisis from Table 2:

$1.313-(1.090)=0.222 \%$

If Australia had not been affected by the COVID-19 pandemic, the country's digital competitiveness index would have grown by $0.222 \%$ in 2020 compared to 2019 .

\section{World economy's forecast, 2021}

Based on the above data, a forecast of the world economy's development for 2021 is made. Expert evaluation allows determining (authors' hypothesis) the two most probable scenarios of development of the COVID-19 pandemic in 2021 and the future:

The scenario of overcoming the viral threat envisages that the development of innovations in the sphere of healthcare (drugs and vaccines) or the independent end of the pandemic (similarly to "Spanish flu" at the beginning of the $20^{\text {th }}$ century) will lead to a reduction of the number of cases in all countries down to $0.5 \%$ of the population - i.e., 5 cases per 1,000 people. Then, the expected growth of the digital competitiveness index will be $(-0.0349 * 50-6.9602) / 100+1=1.0521$, and the expected growth of the sustainable development index will be $(0.0004 * 50+1.0899) / 100+1=1.0111$;

The scenario of reducing the viral threat and normalization of the number of cases envisages COVID-19 becoming a standard (normal) acute respiratory disease, and up to $100 \%$ of the world population will have had it - i.e., up to 1,000 cases per 1,000 people. Then, the expected growth of the digital competitiveness index will be $(-0.0349 * 1,000-6.9602) / 100+1=0.5814$, and the expected growth of the sustainable development index will constitute: $(0.0004 * 1,000+1.0899) / 100+1=1.0149$.

For the forecast, products of the indicators' real values for 2020 and the obtained values of their growth are calculated. It shows the forecast for both scenarios in Table 3.

Table 3 Forecast of development of the world economy after the COVID-19 crisis (2021) 


\begin{tabular}{|c|c|c|c|c|}
\hline \multirow[t]{3}{*}{ Country } & \multicolumn{4}{|c|}{ Forecast of development of the world economy after the COVID-19 crisis (for 2021) } \\
\hline & \multicolumn{2}{|c|}{$\begin{array}{l}\text { According to the scenario of overcoming } \\
\text { the viral threat }\end{array}$} & \multicolumn{2}{|c|}{$\begin{array}{l}\text { According to the scenario of reduction of } \\
\text { the viral threat and normalization of the } \\
\text { number of cases }\end{array}$} \\
\hline & $\begin{array}{l}\text { Digital } \\
\text { competitiveness } \\
\text { index, points 1- } \\
100\end{array}$ & $\begin{array}{l}\text { Sustainable } \\
\text { development } \\
\text { index, points 1- } \\
100\end{array}$ & $\begin{array}{l}\text { Digital } \\
\text { competitiveness } \\
\text { index, points 1- } \\
100\end{array}$ & $\begin{array}{l}\text { Sustainable } \\
\text { development index } \\
\text { points } 1-100\end{array}$ \\
\hline Australia & 78.031 & 75.701 & 49.693 & 75.985 \\
\hline Austria & 75.892 & 81.596 & 48.331 & 81.902 \\
\hline Argentina & 44.537 & 73.982 & 28.363 & 74.260 \\
\hline Belgium & 70.276 & 80.847 & 44.754 & 81.151 \\
\hline Bulgaria & 51.394 & 75.600 & 32.730 & 75.884 \\
\hline Brazil & 47.560 & 73.477 & 30.288 & 73.753 \\
\hline Hungary & 51.047 & 78.198 & 32.508 & 78.492 \\
\hline Venezuela & 21.903 & 62.365 & 13.948 & 62.599 \\
\hline Germany & 74.005 & 81.666 & 47.129 & 81.973 \\
\hline Greece & 51.316 & 75.155 & 32.680 & 75.437 \\
\hline
\end{tabular}

Source: Fragment of the dataset [5]

Let us consider the calculations performed in the example of Australia. The digital competitiveness index was 85.472 points in 2020 , according to the scenario of overcoming the viral threat in 2021 . We find the product of the digital competitiveness index for 2020 and its expected growth. As noted earlier in this section, the expected growth of the digital competitiveness index will be 0.9129 . It follows 85.472 * $0.9129=78.031$ points; reducing the viral risk and normalization of the number of cases will be 85.472 * $0.5814=49.693$ points. The sustainable development index in Australia is 74.9 points. The scenario of overcoming the viral threat in 2021 will be $74.9 * 1.0111=75.701$ points. The scenario of reducing the viral threat and normalization of the number of cases will be $74.9 * 1.01449=75.985$ points.

The advantage of the described method is the accurate assessment of the digital competitiveness index's growth and sustainable development index: the calculated growth is cleared of the other factors' influence. It characterizes the impact of the pandemic and the COVID-19 crisis. This allows the most reliable determination of the impact of the pandemic and makes the most accurate forecast. The strength of the proposed methodology is also the alternativeness of the considered scenarios, making it possible to use the estimates in a wide range of applied papers to investigate the digital economy and sustainable development, both individually and taken together. The scenarios help make managerial decisions in health care state regulation in 2021 and subsequent periods since the forecast shows the consequences 
of overcoming the viral threat and reducing the digital economy's impact and sustainable development. In particular, the forecast and scenarios can support the need for vaccination against the COVID-19 and the continuation or removal of restrictions on social interactions (social distancing).

Therefore, overcoming the viral threat will allow for the continuation of the world economy's rapid digital growth and recover the opportunities lost in 2020 under the pandemic's influence. Reducing the viral threat and normalization of the number of cases will actualize sustainable development. It will draw the world community's attention to it for overcoming future viral threats. This will allow achieving sustainability and stability of the world economy, with a substantial slowdown of digitalization.

\section{Discussion}

The value of the data is explained as follows:

The dataset has statistics on digital competitiveness, sustainable development, and COVID-19 cases for 63 countries globally (63 countries are included in the dataset because the World Digital Competitiveness Report 2020 contains only 63 countries) and includes both developed developing countries. We present the data in an editable form that is prepared for calculations with any level of automatization. The dataset is a convenient digital database for a cross-country overview of the tendencies and perspectives of developing the world economy during and after the COVID-19 crisis from sustainability (and stability) and rapid digital growth. We could use the essential statistical data that are packed in the dataset for further scientific research.

Compared to IMD's basic reports [1] and UNDP [3], this dataset's advantage is data provision in dynamics for 2019-2020 in a combined table. This allows the use of the dataset for thorough dynamic scientific research of the world economy's digitalization and sustainability development, connection (regression dependence) between the number of COVID-19 cases and digital competitiveness and sustainability, and between the number of COVID-19 cases and their change (growth) in the 2019-2020 dynamics. Due to this, the persistent connection is more precise and valuable for many studies.

The dataset also precisely determines the digital competitiveness index's growth and the sustainable development index under the crisis's influence in 2020. Unlike simple growth compared with 2019, the calculated growth contains no impact from other factors, if not the pandemic and the COVID-19 crisis. The dataset overcomes the data deficit on the pandemic's influence and the COVID-19 crisis on economic systems, filling this gap with precise quantitative data for an extensive selection of developed and developing countries.

The practical significance and usefulness of the dataset also consist of evaluating lost profit (lost opportunities in 2020) - due to the COVID-19 crisis - in terms of digital competitiveness and sustainable development in 2020. Lost profit reflects the difference between simple growth indicators in 2020 and 2019 (due to many factors) and growth under the crisis's influence (due to the COVID-19 pandemic). This allows us to see how the world economy could have developed in 2020 without the crisis. 
The dataset contains a forecast of the development of the world economy after the COVID-19 pandemic (for 2021), according to the scenario of overcoming viral threats and reducing viral risk and normalization of the number of cases. This forecast might be helpful for scientific studies that require analytical support and forecast data. The advantage of the compiled forecast is the alternativeness of the considered scenarios, which allows the estimates in a wide range of scientific studies.

The article contributes to the literature by developing the theory of the ethical use of information. In contrast to the existing literature (Emmanuel et al. [20], Ferretti et al. [21, 22], Grybauskas et al. [23], Jantavongso and Fusiripong [24], Ngan and Kelmenson [25], Novak and Pavlicek [26], Reps et al. [27], Robinson [28], Roche and Jamal [29], Seliya et al. [30]) this article proved that Big data ethics is a complex concept: data can be considered ethical not only in the case of their reliability but also in the case of their completeness, justified as a new criterion for the ethics of Big data. The article reveals a new perspective on the ethics of Big data - from the point of view of information users.

\section{Conclusions}

The paper has shown a definite alternativeness of the digital economy and sustainable development progress. The example of the COVID-19 pandemic has been demonstrated that the viral threat is a severe factor determining the prospects for developing socio-economic systems in the future, in the period at least until the post-pandemic period (2025). Economic policy in health care creates conditions for either the development of the digital economy or sustainable development.

The scenario of overcoming the viral threat envisages that the development of innovations in the sphere of healthcare (drugs and vaccines) or the independent end of the pandemic will lead to a reduction of the number of cases in all countries down to $0.5 \%$ of the population - i.e., 5 cases per 1,000 people. Then, the expected growth of the digital competitiveness index will be 0.9129 , and the predicted growth of the sustainable development index is 1.0111. This scenario will allow for the continuation of the world economy's rapid digital growth and replete the opportunities lost in 2020 under the influence of the pandemic.

An alternative to reducing the viral threat and normalization of the number of cases envisages COVID-19 becoming a standard (normal) acute respiratory disease. Up to $100 \%$ of the world population will have it - i.e., up to 1,000 cases per 1,000 people. The expected growth of the digital competitiveness index will then be 0.5814 , and the expected growth of the sustainable development index will be 1.0149 .

Implementing this scenario will cause the normalization of cases to actualize sustainable development. It will draw the attention of the world community to it for overcoming future viral threats. It will allow achieving sustainability and stability of the world economy, despite a substantial slowdown.

The study's contribution is to form a methodological base for decision-making in health care state regulation under acute viral threats in crisis conditions. Traditional statistics do not fully cover data on the virus threat and cite them separately from socio-economic data unsystematically. The existing methodological approaches to health care regulation focus on stability and are not adapted to pandemic 
conditions. The dataset and this study are meant to overcome uncertainty and guarantee high healthcare management efficiency in the downward phase of the economic cycle under the virus threat's influence.

Summing up, we should note that the COVID-19 statistics are subject to constant changes during the ongoing pandemic, which is the study's weakness. The dataset's relevance and analytics will gradually decrease and move into the category of materials on the past phases of the pandemic and archive data, which is an inevitable disadvantage of any statistics.

To maintain the relevance of the dataset and its analytics, we studied the COVID-19 crisis throughout the entire period of the pandemic and in the post-pandemic period.

\section{Declarations}

\section{Ethics approval and consent to participate}

Not applicable

Consent for publication

Not applicable

Availability of data and materials

The datasets generated during and/or analysed during the current study are available in the iscvolga.ru repository, https://iscvolga.ru/data1

The datasets generated during and/or analysed during the current study are available in the Mendeley Data repository, http://dx.doi.org/10.17632/gpvjxsdzjr.1

Competing interests

The authors declare that they have no competing interests

\section{Funding}

No funding

Authors' contributions

E.P., writing, original draft; A.B., methodology, data analysis; S.L., resources and software; E.M., writing, data curation; B.S., writing and editing, supervision.

Acknowledgements

Not applicable 


\section{References}

[1] IMD, World Digital Competitiveness Ranking 2020.

https://www.imd.org/wcc/world-competitiveness-center-rankings/world-digital-competitiveness-rankings2020/, 2020 (accessed 05.11.2020)

[2] Institute of Scientific Communications, Dataset "Big Data of the modern world economy: digital platform for intellectual analytics - 2020".

https://iscvolga.ru/data1, 2020 (accessed 05.11.2020)

[3] UNDP, Sustainable Development Report 2020: The Sustainable Development Goals and COVID-19. https://sdgindex.org/reports/sustainable-development-report-2020/, 2020 (accessed 05.11.2020)

[4] Infotables, Table "Number of COVID-19 cases and number of COVID-19 deaths in countries of the world as of November 2020 (online table).

https://infotables.ru/meditsina/1197-tablitsa-koronavirusa, 2020 (accessed 05.11.2020)

[5] E.G. Popkova, B.S. Sergi, Dataset of perspectives of the world economy's development after the COVID19 crisis, Mendeley Data, V1, http://dx.doi.org/10.17632/gpvjxsdzjr.1, 2020 (accessed 09.11.2020)

[6] W. Perry, Social sustainability and the argan boom as green development in Morocco. World Development Perspectives, 20, (2020). https://doi.org/10.1016/j.wdp.2020.100238

[7] T.Q.A. Le, Y. Shimamura, H. Yamada, Information acquisition and the adoption of a new rice variety towards the development of sustainable agriculture in rural villages in Central Vietnam. World Development Perspectives, 20, (2020). https://doi.org/10.1016/j.wdp.2020.100262

[8] E. Asiedu, S.S. Sadekla, G.A.Bokpin, Aid to Africa's agriculture towards building physical capital: Empirical evidence and implications for post-COVID-19 food insecurity. World Development Perspectives, 20, (2020). https://doi.org/10.1016/j.wdp.2020.100269

[9] Z.M. Gitonga, M.Visser, C. Mulwa, Can climate information salvage livelihoods in arid and semiarid lands? An evaluation of access, use and impact in Namibia. World Development Perspectives, 20, (2020). https://doi.org/10.1016/j.wdp.2020.100239

[10] J. Hellewell, et al., Feasibility of controlling COVID-19 outbreaks by isolation of cases and contacts. Lancet Global Health, 8, (2020) e488-e496.

[11] R. M. Anderson, H. Heesterbeek, D. Klinkenberg, \& T. D. Hollingsworth, How will country-based mitigation measures influence the course of the COVID-19 epidemic? Lancet, 395, (2020) 931-934. 
[12] A. Mandel, \& V. Veetil, The economic cost of COVID lockdowns: an out-of-equilibrium analysis. Economic Disasters Climate Change, 4, (2020) 431-451.

[13] D. Ivanov, Predicting the impacts of epidemic outbreaks on global supply chains: a simulation-based analysis on the coronavirus outbreak (COVID-19/SARS-CoV-2) case. Transp. Res. E 136, (2020) 101922.

[14] H. Inoue, \& Y. Todo, The propagation of the economic impact through supply chains: the case of a mega-city lockdown to contain the spread of COVID-19. COVID Econ. 2, (2020) 43-59.

[15] Y. Shan, J. Ou, D. Wang, et al., Impacts of COVID-19 and fiscal stimuli on global emissions and the Paris Agreement. Nature Climate Change, (2020). https://doi.org/10.1038/s41558-020-00977-5

[16] Yekefallah, L., Namdar, P., Panahi, R., Dehghankar, L. Factors related to students' satisfaction with holding e-learning during the Covid-19 pandemic based on the dimensions of e-learning/ Heliyon (2021). 7(7), e07628 https://doi.org/10.1016/j.heliyon.2021.e07628

[17] Olonade, O.Y., Oyibode, B.O., Idowu, B.O., (...), Egharevba, M.E., Adetunde, C.O. Understanding gender issues in Nigeria: the imperative for sustainable development. Heliyon (2021). 7(7), e07622. https://doi.org/10.1016/j.heliyon.2021.e07622

[18] Prayitno, G., Dinanti, D., Hidayana, I.I., Nugraha, A.T. Place attachment and agricultural land conversion for sustainable agriculture in Indonesia. Heliyon (2021). 7(7), e07546. https://doi.org/10.1016/j.heliyon.2021.e07546

[19] Chalongvorachai, T., Woraratpanya, K. A data generation framework for extremely rare case signals. Heliyon (2021). 7(8), e07687. https://doi.org/10.1016/j.heliyon.2021.e07687

[20] Emmanuel, T., Maupong, T., Mpoeleng, D., (...), Mphago, B., Tabona, O. A survey on missing data in machine learning. Journal of Big Data (2021), 8(1), 140. https://doi.org/10.1186/s40537-021-00516-9

[21] Ferretti, A., lenca, M., Sheehan, M., (...), Rivas Velarde, M., Vayena, E. Ethics review of big data research: What should stay and what should be reformed? BMC Medical Ethics (2021a), 22(1), 51. https://doi.org/10.1186/s12910-021-00616-4

[22] Ferretti, A., lenca, M., Velarde, M.R., Hurst, S., Vayena, E. The Challenges of Big Data for Research Ethics Committees: A Qualitative Swiss Study. Journal of Empirical Research on Human Research Ethics (2021b). https://doi.org/10.1177/15562646211053538

[23] Grybauskas, A., Pilinkienè, V., Stundžienè, A. Predictive analytics using Big Data for the real estate market during the COVID-19 pandemic. Journal of Big Data (2021), 8(1), 105. https://doi.org/10.1186/s40537-021-00476-0

[24] Jantavongso, S., Fusiripong, P. Ethics, big social data, data sharing, and attitude among the millennial generation: A case of Thailand. Electronic Journal of Information Systems in Developing 
Countries (2021). 87(5), e12179. https://doi.org/10.1002/isd2.12179

[25] Ngan, O.M.Y., Kelmenson, A.M. Using Big Data Tools to Analyze Digital Footprint in the COVID-19 Pandemic: Some Public Health Ethics Considerations. Asia-Pacific Journal of Public Health (2021). 33(1), 129-130. https://doi.org/10.1177/1010539520984360

[26] Novak, R., Pavlicek, A. Data experts as the balancing power of big data ethics. Information (Switzerland) (2021). 12(3),97, 1-14. https://doi.org/10.3390/info12030097

[27] Reps, J.M., Ryan, P.B., Rijnbeek, P.R., Schuemie, M.J. Design matters in patient-level prediction: evaluation of a cohort vs. case-control design when developing predictive models in observational healthcare datasets. Journal of Big Data (2021), 8(1), 108. https://doi.org/10.1186/s40537-021-00501-2

[28] Robinson, K. A false promise of COVID-19 'big' health data? Health data integrity and the ethics and realities of Australia's health information management practice. Health Information Management Journal (2021), 50(1-2), 9-12. https://doi.org/10.1177/1833358320941190

[29] Roche, J., Jamal, A. A Systematic Literature Review of the Role of Ethics in Big Data. Advanced Sciences and Technologies for Security Applications (2021), 327-342. https://doi.org/10.1007/978-3-03068534-8_20

[30] Seliya, N., Abdollah Zadeh, A., Khoshgoftaar, T.M. A literature review on one-class classification and its potential applications in big data. Journal of Big Data (2021), 8(1), 122. https://doi.org/10.1186/s40537-021-00514-x

\section{Figures}




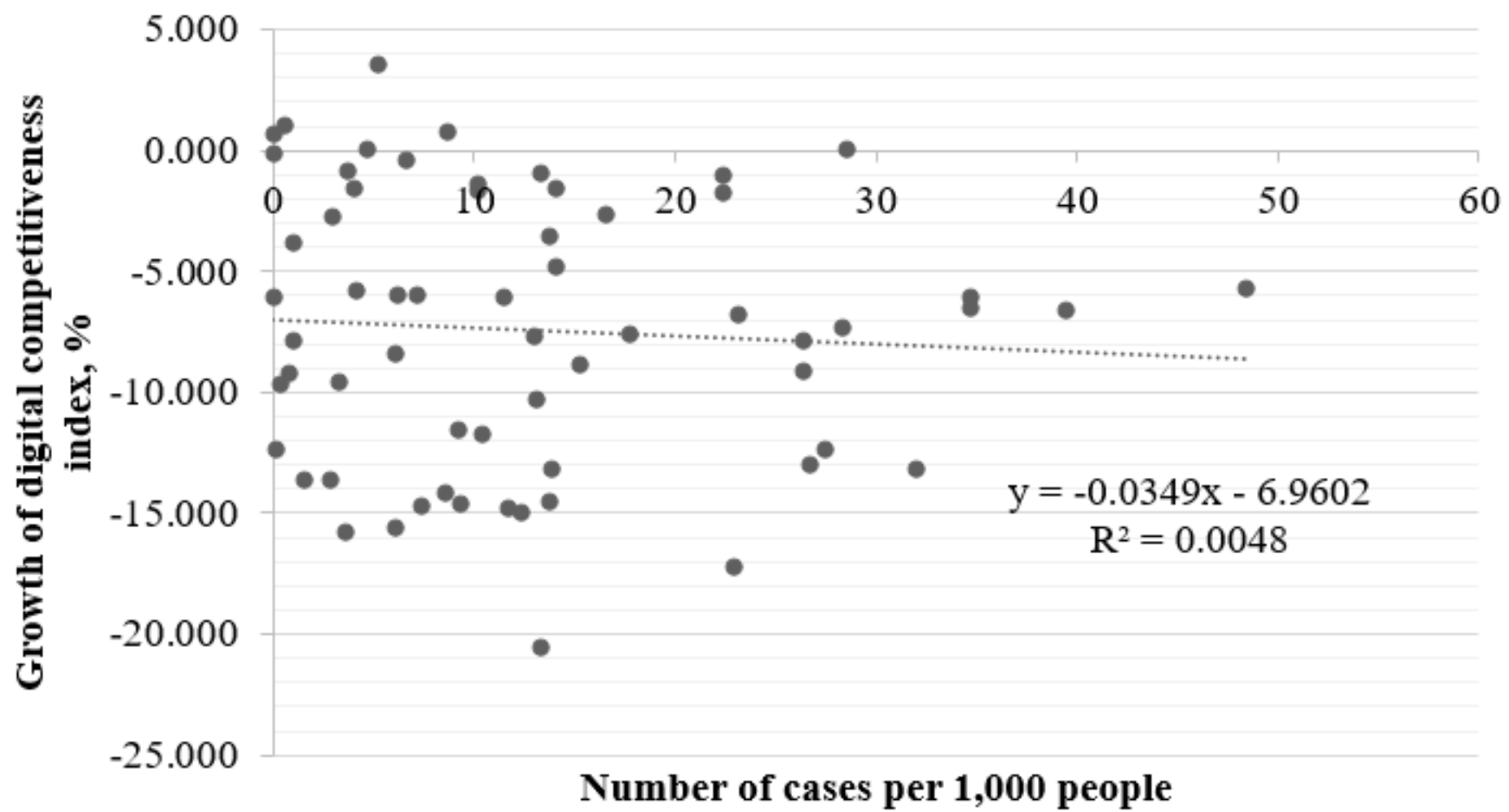

Figure 1

Regression curve of the dependence of growth of digital competitiveness index on the number of COVID19 cases

Source: Fragment of the dataset [5] 


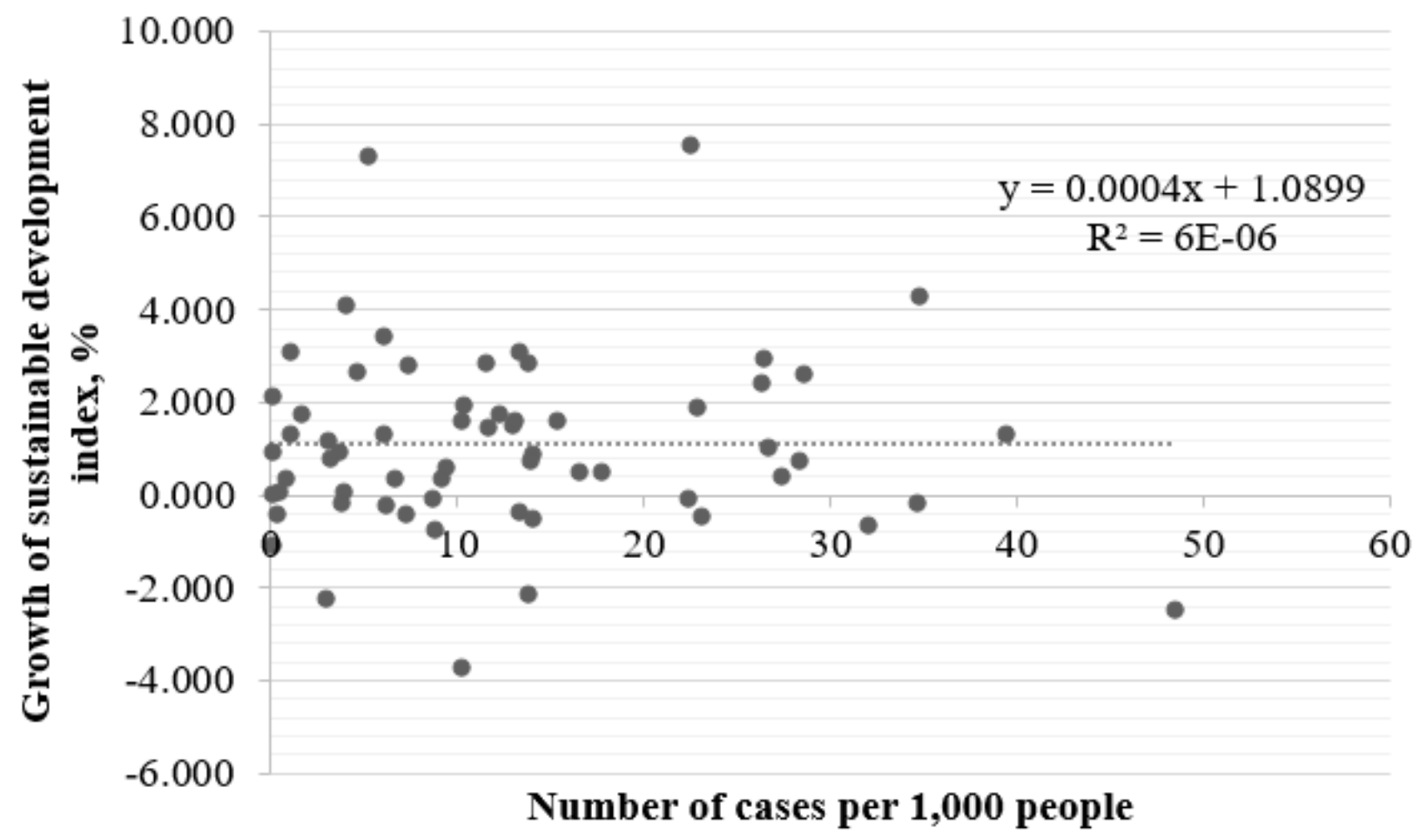

Figure 2

Regression curve of the dependence of growth of sustainable development index on the number of COVID-19 cases

Source: Fragment of the dataset [5] 